\title{
THEMEANING OF TEPAK SIRIH TRADITION IN TANJUNGBALAI MALAY WEDDING CEREMONY
}

\section{AN ARTICLE}

\section{Submitted in Partial Fulfillment of the Requirements}

for the Degree of Sarjana Sastra

By

ADE IRMA MARPAUNG

Registration Number: 2142220001

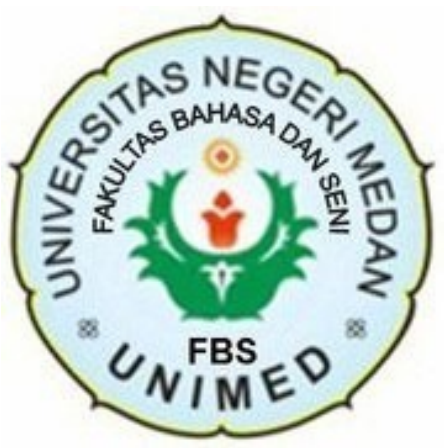

ENGLISH AND LITERATURE DEPARTMENT

FACULTY OF LANGUAGES AND ARTS STATE UNIVERSITY OF MEDAN 2018 


\section{ARTIKEL \\ THE MEANING OF TEPAK SIRIH TRADITION IN TANJUNGBALAI MALAY WEDDING CEREMONY \\ Disusun dan Diajukan oleh: \\ Ade Irma Marpaung \\ NIM. 2142220001}

Telah diverifikasi dan dinyatakan memenuhi syarat

untuk diunggah pada jurnal online

Medan, Oktober 2018

\section{Menyetujui}

Dosen Pembimbing Skripsi I

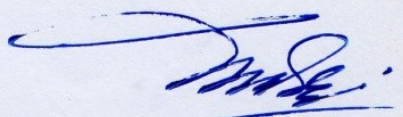

Prof. Dr. Zainuddin, DIP.TEFL., M. Hum.

NIP. 195201021980121001

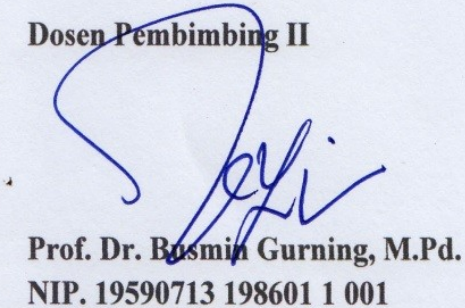

Ketua Prodi Sastra Inggris

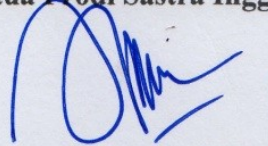

Juli Rachmadani, S.S., M. Hum.

NIP. 198207112008012008 


\title{
The Meaning of Tepak Sirih Tradition In Tanjungbalai Malay Wedding Ceremony
}

\author{
Ade Irma Marpaung \\ Prof. Dr. Zainuddin, DIP.TEFL.,M.Hum \\ Prof. Dr. Busmin Gurning, M.Pd \\ Universitas Negeri Medan
}

\begin{abstract}
This study is concerned at finding the meanings of Tepak Sirih tradition in Tanjungbalai Malay wedding ceremony. either it is the meaning of offering tepak sirih and the meanings that found in all objects that needed to practice tepak sirih tradition. This study also concerned on how and why the meanings realized in practicing tepak sirih. The research method used in this paper is descriptive qualitative method which is related to the grounded theory where the meanings are elaborated by using Roland Barthes's Semiology Theory. The interview was assisted by two interviewees who are expert about Tanjungbalai Malay culture and tradition and they are the speakers in every ceremony of Malay in Tanjungbalai. The results showed that offering tepak sirih have different meaning in different event. Merisik, meminang and Hempang pintu are three events that use tepak sirih tradition in Tanjungbalai Malay wedding but only hempang pintu which uses tepak sirih in the wedding ceremony. The writer found There were 11 dennotative meanings, 7 connotative meanings and two myths in all objects that needed in doing tepak Sirih tradition. The reason Tepak sirih is seen as the tool of communication or the opening speech in Tanjungbalai Malay wedding ceremony lies on the history of Tanjung balai Malay living in the past.
\end{abstract}

Keywords: Semiotic or Semiology, Tepak sirih, Tanjungbalai Malay

\section{A. Introduction}

Tradition is Part of Culture. Every culture has its own tradition. Culture and tradition are two things that can't be separated. Human being as cultural creature has tradition as their belief passed down within a group or society with special significance.Sinaga (2013:12) stated that culture and tradition is the invention of human's intelligence. The language people speak and the way people create style are all the aspects of culture.

A group of people who are Islamic, speak in Malay language and holding tight malay culture in their daily life is called as Tanjungbalai Malay. As a matter of fact Tanjungbalai is a town that dominated by the fisheries sector because the town is located in coastal area. So most of societies earn their living as being fisherman. Having a job as fisherman is supported by the 
port of Teluk Nibung as the second largest port in North Sumatera after Belawan port.Besides Tanjungbalai Malay, there are Deli Malay, Riau Malay, Jambi Malay, Bengkulu Malay, Tamiang Malay, Palembang Malay, Sambas Malay, Bangka-Belitung Malay and Pontianak Malay. As the third largest ethnic group in Indonesia, Malay also has many traditions (Mutiara, 2016:5).

Tanjungbalai Malay is viscous of culture and tradition especially in marriage Custom. According to Rahmat Kartolo in his research article about "Language Meanings and Symbols in the Traditional Wedding Ceremony of Malay Deli, malay society has24 kinds of procedure of marriage.But, among those 24 procedures of Marriage in Malay, only merisik Asking for marriage (meminang) and Hempang pintu which use Tepak Sirih tradition to complete the malay wedding culture.

Tepak sirih plays an important role in malay marriage tradition. Malay traditional event will not perfect without bringing the tepak sirih. Malay society believe that if the marriage custom especially when doing proposing (meminang) does not carry out tepak sirih, it means that the people do not know the custom and they call this type of people as orang yangtidak tahu adat (people who do not follow rules).

Unfortunately nowadays, most of Malay society especially Tanjungbalai Malay, they actively use tepak sirih tradition but they less understand the meaning or the cultural significance behind the tradition that they do. Whereas in fact, tepak sirih as malay culture heritage is rich in meaning and it has noble value that needed to be preserved because many aspect of human's regulation in life are found in tepak sirih tradition to achieve the perfect goal. Tepak sirih tradition must be introduced and inherited to young and next generation so that they know the importance of tepak sirih tradition for malay society and they know the meaning behind this tradition as part of life as culture society.

To get the meanings in Tepak sirih tradition, it is needed to review the theory about culture such as Semiotics. Because semiotic is a science that concern on production and interpretation of meaning. Semiotic is a sience of the production and interpretation of meaning. Its basic principle is meaning is made by the development of acts and objects (Anugerah, 2016:14). There have been some previous studies that related to the tepak sirih tradition as malay culture heritage. But there is a previous study which become the writer's consideration in conducting this study. Siti Hajar (2016) conducted a study with the intention of identifying and examining the role of tepak sirih in malay marriage custom. This research concern on informing 
us how the tepak sirih plays an important role for malay society in marriage custom. This research will be diffent with the previous study. This research concern on describing the meaning of tepak sirih tradition itself, so in addition the malay society actively use this tradition, they also know the meaning or cultural significance behind that tradition.

\section{B. Theoretical Framework}

This study focuses on analyzing the meanings of tepak sirih tradition in Tanjungbalai Malay wedding ceremony. To get the meanings in Tepak sirih tradition, it is needed to review the theory about culture such as Semiotics. Because semiotic is a science that concern on production and interpretation of meaning (Merianita, 2012:2).

This study concerned on the meanings of offering tepak sirih and the meanings that found in all object that needed to practice tepak sirih. Barthes's Semiology theory is used in this research to find the dennotative and connotative meanings in practicing Tepak sirih tradition in Tanjungbalai wedding ceremony. In semiotic the meaning of the object is called as the signified, while the object that carries the meaning is the signifier. The signified is not always in forms of real objects. The relation between signifier and signified is then divided by Barthes into two different levels of system, which are denotative and connotative. Denotative meaning is a simple, basic, descriptive signification where meaning resulted is agreed upon a common consensus. On the other hand, the connotative meaning is no longer a signification of a clear interpretation on the descriptive level, but it is rather closely related to "fragments of an ideology, a very close communication with culture knowledge (Graham, 18:2003).

The writer is also focuses on finding out the reason why the meanings are realized. To answer all the whole research's problems the writer did an observation to observe how do Malay societies practice tepak sirih in Tanjungbalai and to get the detailed and clear data the writer interviewed two interviewees who knows very well about tanjungbalai malay wedding culture and tradition especially about tepak sirih tradition. Finally, after analyizng the result of interviews all of the research problems can be answered by the writer as the findings.

\section{Tepak Sirih}

Tepak sirih is an item that is often used in Malay community, especially when holding wedding tradition. Generally, tepak sirih known as a symbol for the 
Malay community to deliver a purpose and desire (Delima, 2014:17). The researcher define tepak sirih as an object that its existing is highly required in Malay wedding tradition because tepak sirih is seen as symbol to deliver a purpose and desire for a man who want to propose a woman that he loved.

Tepak sirih plays an important role in malay marriage tradition. Malay traditional event will not perfect without bringing the tepak sirih. Malay society believe that if the marriage custom especially when doing proposing (meminang) does not carry out tepak sirih, it means that the people do not know the custom and they call this type of cembul people as orang yangtidak tahu adat (people who do not follow rules). The way tanjung balai malay practiced tepak sirih tradition must follow the rules that have been dealed by the old generation who knows malay culture well or malays called it as orang yang beradat. Practicing tepak sirih tradition in malay wedding isn't allowed to be careless because if malay do the tepak sirih without following the rules the tepak sirih that have been prepared must not accepted. First thing that must be prepared in doing tepak sirih tradition is preparing the tools that required in tepak sirih tradition. The tools are tepak filler or pengisi tepak, cembul, bekas sirih, kacip and gobek.

Tanjungbalai Malay claimed that tepak filler (pengisi tepak) consists 5 objects. 4 objects are planted and one object is burned.The four objects that planted are Daun sirih/Betel leaves, Pinang/ betel nut, Kapur / lime andTembakau/ Tobacco. One object that is burned is Gambier. So, according to tanjungbalai Malay, the first thing that must be put on cembul is pinang. Make sure the pinang or betel nut had been cut into smaller part, after that put lime or kapur on the second cembul, and then put gambier on the third and the last thing that must be put on the fourth cembul is tobacco.

\section{Research Methodology}

This research was conducted to get the meanings of Tepak Sirih tradition in Tanjungbalai Malay by Using Roland Barthes's Semiology theory. This research used descriptive qualitative method. Descriptive qualitative method is also called as ethnography method because mostly this method used in field research of cultural antrophology (Sugiyono, 2014:8). In conducting this qualitative research, the writer used documentary and interview techniques. The data of this research were all meanings found in tepak sirih. Meanwhile, the sources of data were the practiced of tepak sirih tradition and also two informants who knows very well about tepak sirih tradition in Beting Seroja Kelurahan Keramat Kubah. 


\section{E. Findings and Discussion}

\section{The meanings of offering Tepak Sirih in Tanjungbalai wedding ceremony.}

The meaning of offering tepak sirih is interpreted as an object that functions as tool of communication. The point is the offering of tepak sirih have different meaning in different event. The meaning of offering Tepak Sirih in Merisik is interpreted as Tepak Perkenalan, the meaning of offering Tepak Sirih in asking for marriage or meminang is interpreted as tepak mengikat janji while the meaning of offering tepak sirih in hempang pintu is interpreted as tepak menepati janji.

\section{How are the meanings realized}

The meanings realized in the offering and practicing tepak sirih was found by analying and categorizing the meanings. Barthes's Semiology theory was used in this research to find the dennotative and connotative meanings in practicing Tepak sirih tradition in Tanjungbalai wedding ceremony. In semiotic the meaning of the object is called as the signified, while the object that carries the meaning is the signifier. The signified is not always in forms of real objects. The relation between signifier and signified is then divided by Barthes into two different levels of system, which are denotative and connotative. Denotative meaning is a simple, basic, descriptive signification where meaning resulted is agreed upon a common consensus. On the other hand, the connotative meaning is no longer a signification of a clear interpretation on the descriptive level, but it is rather closely related to "fragments of an ideology, a very close communication with culture knowledge.

The semiosis (meaning analysis) that found in Tepak sirih tradition

\begin{tabular}{|c|c|c|c|c|}
\hline \multirow[t]{2}{*}{ No } & \multirow{2}{*}{$\begin{array}{c}\text { Necessary equipment } \\
\text { in doing tepaksirih } \\
\text { tradition }\end{array}$} & \multicolumn{3}{|c|}{$\begin{array}{c}\text { Two orders of Signification by Roland } \\
\text { barthes semiology theory }\end{array}$} \\
\hline & & Denotative & Connotative & Myth \\
\hline$A$ & BungaMawar & $\checkmark$ & $\checkmark$ & \\
\hline $\mathrm{B}$ & BungaKenanga & $\checkmark$ & & \\
\hline C & Cembul & $\checkmark$ & & \\
\hline $\mathrm{D}$ & Gambir & $\checkmark$ & $\checkmark$ & \\
\hline$E$ & Bekas Sirih & $\checkmark$ & & \\
\hline$F$ & Kapur & $\checkmark$ & $\checkmark$ & \\
\hline $\mathrm{G}$ & Ketur & $\checkmark$ & & \\
\hline $\mathrm{H}$ & Mayang & $\checkmark$ & $\checkmark$ & \\
\hline I & Pinang & $\checkmark$ & $\checkmark$ & $\sqrt{ }$ \\
\hline $\mathrm{J}$ & Sirih & $\checkmark$ & $\checkmark$ & $\checkmark$ \\
\hline
\end{tabular}




\begin{tabular}{|c|c|c|c|c|}
\hline $\mathrm{K}$ & Tembakau & $\checkmark$ & $\checkmark$ & \\
\hline $\mathrm{L}$ & Nut Racker/Kacip & $\checkmark$ & & \\
\hline
\end{tabular}

\section{1 Table of Semiosis}

a Rose

Its denotative meaning is a type of flowering shrub. The name of rose grow in many different colors, from the well known red, white and yellow rose.

While the connotative meaning of roseFor malay society rose in tepaksirihtradition is interpreted as the head of tepak or kepalatepak. Because commonly rose is interpreted as beautiful lady. And tepaksirihis used to propose lady so rose is seen as the head of tepak which propose a beautiful lady.

$b$ Kenanga

The dennotative meaning of ylang flower or it is well known as cananga tree is a tropical tree that is native to Indonesia, Malaysia and philipines.

c Cembul

The dennotative meaning of cembul was an important part that concists of four items. It functioned as container for the betel nut, lime, gambier and tobacco.the cembul shape was circular with the top on it and its lower side is flat so that it could stand upright. Cembul was made from metal materials such as copper, silver and sometimes overlaid with gold. The outer side of cembul and its top was usually trimmed with various carved objects such as gold leaves, pelur flowers and other artistic ornaments.

\section{d Gambier}

Gambier could be denotated as a genus of flowering plants in the family of Rubiacea, native to East Asia, the gambier leaves has egg shaped leaves, smooth glossy surface and gray flower.

While the connotative meaning of gambier was symbolizes the stoutness of heart.

\section{e Bekas sirih}

The dennotative meaning of bekas sirih was a place to put betel leaves. Occasionally the betel leaves didn't put in tepak sirih but in a separate container called bekas sirih. bekas sirih was made from metal or silver and overlaid with golden.

\section{$f$ Kacip}

The dennotaive meaning of kacip or nut racker was a tool that functioned as a knife that consist of two chips. Sharp moving chip located at the upper side and blunt hanging chip . it was used to rack and mince betel nut/ pinang. 


\section{$g$ Kapur}

The dennotaive meaning of kapur was white and tough like a cream. It was extracted from burned cockle shells until become a powder addedd with wome water, the powder was lubricated on the betel leaves.

Kapur also has its connotative meaning. The connotative meaning of kapur refers to the purity of heart that conveyed the nobility and purity.

h Ketur

The dennotative meaning of ketur was a place for spitting. The betel leaves that eaten with kapur, gambier and betel nut would produce red, heavy, thick and dirty spittie so that people who ate the betel leaves will often expectorate.

i Mayang

The connotative meaning of mayang was it symbolized that the woman that were going to propose/ dipinang was a girl. Actually, the tepak sirih wich didn't put mayang on it symbolized that the woman that were going to married was a widow.

j Betel nut/Pinang

Pinang has its dennotative, connotative even myth. The dennotative meaning of pinang was fruit of plant growing mostly in troppical areas. The plant whose tip has pointed shape was medium sized tree growing to $10 \mathrm{~m}$ tall with trunk 15 to $20 \mathrm{~cm}$ in diameter.

The connotative meaning of pinang was it represented the noble descent or heritage as well as honesty and integrity. There was a message that tanjungbalai malay could take from pinang, malay tanjungbalai could imitate the way this plants grew and survive. Pinang which comes from the tall and slender palm tree reflects the willingness to do a specific job in proper manner.

\section{k Betel leaves/ daun sirih}

Betel leaves also has dennotative, connotative and myth. The dennotative meaning of betel leaves was a subtropical plant growing in Asia, Madagascar, east Afrika and West Hindia. The botanical for the betel leaves was piper betel which was part of Piperaceae's family. The plant was known by a series of different names in the regions in which it is consumed.

The connotative meaning of betel leaves refer as the symbol of respects for other, generosity and altrusity. The myth that found in betel leaves was understood from the betel leaves grow in which they live in and creep the woods or trees they like without creating any harm. The thick and dense leaves provieded calm, quietness and shelter for their surronding. So tanjungbalai malay people took a message from the this betel leaves grew 
and reflected on malay tanjungbalai living. People who lived as a wife and husband must respect each other, altruisity, quietness and shelter around their surronding.

\section{Tobacco}

The dennotative meaning of tobacco was an agricultural product planted for its fresh leaves usually used for main ingredients of cigarette. Tobacco was in the genus of solance family. One of the advantage of tobacco was it could be cultivated in any different season.

While the connotative meaning of tobacco that related the tanjungbalai malay philosopy was reflected determination and willingness to make sacrifice for other sake.

Totally, there were 11 dennotative meanings, 7 connotative meanings and 2 myths found in all objects that needed to practice tepak sirih tradition. All meanings were got based on the result of interview with Rajo Hafsah on $20^{\text {th }}$ july 2018.

\section{3. the reason sthe meaning realized as they are .}

In answering the reason why the meanings realized as they are, the writer has interviewed Rajo Hafsah as the old generation who know the malay culture well in tanjungbalai. She said that long time ago tanjungbalai malay people did not have good rethoric. The background why they didn't have good rethoric was because the number of people wich were allowed to get proper education was limited. So only keturunan bangsawan which were allowed to get proper education. So only they who know how was the good language in starting the conversation while keturunan rakyat biasa did not know it. So people who lived in tanjunbalai believed and deal that tepak sirih is seen as the tool of communication. They agreed that every people who wants to propose the woman must bring the tepak sirih as the sign that the man has desire to make a good relationship as husband and wife to the woman that the man is going to married.

\section{F. Discussion}

After analyzing and answering all the research problems, there were some important points to be discussed.

It can be seen that this study has some differences with the previous study in relevant study. The previous study concern on the form and role of tepak sirih in Malay wedding custom. Different form of tepak sirih have different role in malay wedding custom. Meanwhile this study focused on the meaning of the tepak sirih tradition in Tanjungbalai Malay wedding ceremony either it was the meaning of offering tepak sirih and the 
meanings that found in all objects that needed to practice tepak sirih. To find the meanings in tepak sirih tradition it is needed to review the theory about culture such as semiotics or semiology.

Semiotic or semiology is a science of production and interpretation of meaning. Its basic principle, meaning is made by the development of acts and objects. In this research, meaning is not only found in language, but also found in culture and tradition such as in tepak sirih tradition. Roland Barthes's Semiology theory organied the data to get the answer of research's problems. Dennotative, connotative and myth as part of roland barthes's semiology theory represented in malay daily life especially for practicing tepak sirih tradition. This study also investigating the reasons why the meaning realized as they are by learnig the history of tepak sirih existing in Tanjungbalai Malay. So, this study is different from the previous study. Dennotative, connotative and myth as part of roland barthes's semiology theory represented in malay daily life especially for practicing tepak sirih tradition in Tanjungbalai wedding ceremony.

In this discussion, it can be seen that the theory really worked in reality. All meaning can be found although in the form of nonverbal communication such as tepak sirih.because the basic principle of semiology is meaning made by the development of acts and objects which functions as signs and in relation to other signs. This research has a good quality in the way it explained and answered the research problems to find the findings.

\section{G. Conclusions}

1. The meanings of offering Tepak Sirih in Tanjungbalai wedding ceremony was interpreted as an object that functions as tool of communication. The point was the offering of tepak sirih have different meaning in different event. The meaning of offering Tepak Sirih in Merisik was interpreted as Tepak Perkenalan, the meaning of offering Tepak Sirih in asking for marriage or meminang is interpreted as tepak mengikat janji while the meaning of offering tepak sirih in hempang pintu is interpreted as tepak menepati janji.

2. The way people practiced tepak sirih tradition must follow the rules that have been dealed by the old generation who knows malay culture well or malays call it as orang yang beradat. Doing the tepak sirih tradition in malay wedding isn't allowed to be careless because if malay do the tepak 
sirih without following the rules the tepak sirih that have been prepared must not accepted and those who don't know the rules will called as orang yang tidak beradat.

3. Totally there were 11 dennotative meaning, 7 connotative meaning and 2 myths were found in all objects that needed to practice tepak Sirih tradition.

4. The Reasons of Malay societies realizing the meaning of tepak sirih tradition as they are because long long ago Tanjungbalai malay did not have good rethoric. The background why they didn't have good rethoric was because the number of people wich were allowed to get proper education was limited. So only gentlehood which were allowed to get proper education. So only they who know how was the good language in starting the conversation while ordianary people did not know it. So people who lived in tanjunbalai believed and deal that tepak sirih is seen as the tool of communication. They agreed that every people who wanted to propose the woman must bring the tepak sirih as the sign that the man has desire to make a good relationship as husband and wife to the woman that the man was going to married.it was the reason why tepak sirih is seen as the tools of communication in Tanjungbalai Malay wedding ceremony. The other reason why betel leaves, pinag, kapur, gambir and tembakau are interpreted as they are because tanjungbalai malay saw the way the plant grew. Such as sirih and pinang for example. 


\section{REFERENCES}

Anugrah, D. (2016).

AnalisisSemiotikaTerhadapProsesiPernikahanAdatjawa

“TemuManten" Di Samarinda.JurnalllmuKomunikasi.

Vol.4,No.1. FakultasllmuSosialdanllmuPolitik:

UniversitasMulawarman.

Ariani, E. (2015). The Values of Education in the Novels "Serials of Anak-AnakMamak" by TereLiye A Study of Structural Semiotics.International Journal of Language Education and Culture Review.Vol.1, Number.2. Jakarta: State University of Jakarta.

Chandler, D. (2007). Semiotics The Basics Second Edition. USA:

Rouledge.

Corbin and Strauss.(2008). Basics of Qualitative Research.

"Techniques and Procedures for Develoving Grounded Theory". New York: Sage Publications.

Delima.(2014).

AdatBudayaMelayuTanjungbalai.Tanjungbalai:MABMIDewan BahasadanPustaka..

Graham, A. (2003). Roland Barthes Semiology. USA: Rouletge.

Hajar, S. (2016).The Role of TepakSirih in Malay Wedding

Custom. Faculty of Humanities, Arts and Heritage: University Technology Mara.

Halina. (2014). The Semiotic Perspective of Peirce and Saussure. Malaysia: University Malaysia Sabah.

Hasyim, M. (2015).Myths and Ideology of Semiotic in Advertisement's Television. International Journal of Communication and Media Studies. Vol.5,No.2. Makassar: Hasanuddin University.

Islamika, (2016). The Meaning of Tumpeng In Javanese Islam. Special Program of Ushuluddin and Humanity Faculty: UIN Walisongo.

Kartolo, R. (2017). Language Meaning and Symbols in The Traditional Wedding Ceremony of Malay Deli. International Journal of Sciences and Humanities Invention. Volume.4,No.7. Medan: Universitas Muslim Nusantara.

Merianita, N. (2012). A Semiotic Study on Tuwuhan at Tarub Decoration of Javanese Wedding Ceremony. FakultasSastra:UniversitasJember (UNEJ).

Mutiara, V. (2016). Sign Analyssis Used In The Pantunof HempangPintu of Pesisir Malay Traditional Wedding Ceremony. Faculty of Languages and Art:State University of Medan. 
Norhuda. (2015). The Use of TepakSirih in Malay Wedding Customs. Faculty of Humanities, Arts and Heritage: University of Malaysia Sabah.

Saragih, A. et.al.(2018). Semiotika. Medan: UNIMED PRESS.

Sinaga, R. (2013). Meninggal Adat Dalihan Na Tolu. Jakarta: Dian Utama.

Sugiyono. (2014). Metode Penelitian Kuantitatif, Kualitatid dan $R \& D$. Bandung: Alfabeta.

Totu, A. (2015). The Semiotic of Bangkai-Bangkaian A Special Space For The Spirit. Faculty of Social Sciences: University of Malaysia Sabah. 